\title{
War Museums in Postwar Lebanon: Memory, Violence, and Performance
}

\author{
Craig Larkin ${ }^{a}$ and Ella Parry-Davies ${ }^{b}$

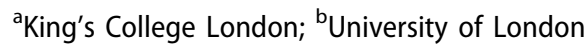

\begin{abstract}
This article examines three museums that address Lebanon's history of conflict: the newly opened Beit Beirut on the capital's former Green Line, the Hezbollah-run Mleeta Resistance Tourist Landmark in south Lebanon, and Umam Documentation and Research's online archive "Memory at Work." Each testing the parameters of what the term museum can mean in Lebanon today, these cases highlight the still-contested nature of war narratives. While many Lebanese youth express desire for a shared national history of the civil war, the affective complexities of recuperated memorial sites and the inconsistent involvement of the state suggest that the possibility of publicly staging such a history is far from secure.
\end{abstract}

\section{Introduction}

Almost three decades after the end of Lebanon's civil war (1975-1990), Beirut has opened its doors to its first museum and cultural center addressing the history of the war, Beit Beirut. While its bullet-pocked exterior bears witness to its location along Beirut's former Green Line, or "intersection of death" (takaata al-mawt), the lack of curator or permanent collection evidences Lebanon's ongoing contestation of its war memory. Lebanon has been diagnosed by scholars, activists, and artists as suffering from social amnesia (lost memory), hypomnesia (poor memory), and hypermnesia (enhanced memory). ${ }^{1}$

Consequently the search to uncover, learn from, or move beyond the past remains a highly politicized field shaped by dominant "memory cultures" ${ }^{2}$ and competing "regimes of memory" vying for representative forms and interpretative power. In the absence of state-led memorial projects, privately funded museums and archives are shaping civil war discourses and debates and are responding to Lebanon's contemporary political realities. This article examines three distinct initiatives commemorating conflict in Lebanon-Beit Beirut Museum and Urban Cultural Centre, Mleeta Resistance Tourist Landmark, and Umam Documentation and Research's (D\&R) "Memory at Work" database ${ }^{4}$ - situating them within internal debates about authenticity and historical truth and international disputes about the memorialization of trauma, conflict, and pain. This research results from a decade-long interest in war memory in Lebanon, ${ }^{5}$ and more explicitly site observations and semi-structured interviews carried out with museum founders, curators, artists, activists, and visitors during January-September 2018. 
Ethnographic fieldwork was supplemented by website and secondary-source analysis, and the creation of an online survey examining the local responses, attitudes, and experiences of Lebanese to war memorials and museums (40 respondents during January 2018).

Each case study under review tests the parameters of the term museum in ways that point toward its complexity in contemporary Lebanon. The article therefore begins by situating the Lebanese case studies within a contemporary genre of museology exemplified by memorials and so-called dark tourism sites across the world, which emphasizes the decentering of knowledge from rigid pedagogical narratives in favor of the participatory and affective experience of viewers. While seeming to shift the balance of agency toward visitors, the effects of this move are not unproblematic, because the powerful affective force of such experiences can foster ideological monopolization. The three Lebanese museums discussed here are located on sites closely connected to the histories in question, exacerbating their experiential intensity and narrative force. In the second section, we discuss how the memorial sites themselves are inscribed with meaning. Finally, we will look at the implications of these projects for national narratives of war, in particular focusing on the presence (or indeed, the absence) of the state in each case. Given the unwillingness of the Lebanese state to participate in or endorse memory-making with respect to the civil war, we address how each museum has negotiated its relationship to the nation and its axes of power, and what this reveals about the current predicament of war memory in Lebanon.

\section{Memory and war museums in divided societies}

Since the early 1990s, a new genre of museums and museology has emerged, entailing a shift from institutional history and pedagogical instruction to a decentered approach to knowledge production through oral testimonies and collective mnemonic participation. ${ }^{6}$ The proliferation of "memorial museums," often located on physical sites of historic suffering, attests to the growing conflation of commemorative practice and emotive narrativization of the past. ${ }^{7}$ Holocaust museums can now be found in more than 30 , while similar memorial museums have been created within former prison camps (Perm-36 Gulag, Russia; Tuol Sleng Genocide Museum, Cambodia), on massacre and burial sites (The Nanjing Massacre Memorial Museum, China; Kigali Genocide Memorial, Rwanda), and on urban spaces of terrorist attacks (9/11 Memorial Museum, New York).

The moral imperative of such museums, according to Silke Arnold-de Simine, encourages visitors "to empathize and identify with individual sufferers and victims, as if "reliving" their experience, in order to thus develop more personal and immediate forms of engagement." "The idea of "secondary witnessing" as a deterrent against future violence may be compelling, yet critics have questioned whether such mnemonic empathy actually fosters "ethical thinking" or "elicits tolerance and deeper understanding." 10 As Susan Sontag suggests, "perhaps too much value is assigned to memory, not enough to thinking." "Other commentators accuse such memory projects of leading to the banalization and commodification of horrific events for mass consumption. The sale of "Twin Tower" hoodies and Search and Rescue toy dogs at the 9/11 Memorial Museum gift shop is a case in point. ${ }^{12}$ Yet the most challenging critique of memorial 
museums surrounds the affective, ideological strategies employed through exhibition narratives and images. ${ }^{13}$ In divided and post-conflict societies, where the past remains a contested field, emotive memorial museums are more often representational battlegrounds for competing historical narratives, communal identities, and the determination of society's victims, heroes, and aggressors.

For Patrizia Violi, the power of such memorial sites derives from their "spatial contiguity with the trauma itself." ${ }^{14}$ Such traces provide testimonial authenticity and emotional intensity to be both interpreted and transformed through the visitor's embodied experience of the site. A performative understanding of memorial sites and activities such as historical reenactment sees visitors as active co-creators engaged in cultural imaginings. ${ }^{15}$ As such, space not only is acted out through existing narratives and patterns of behavior but also can be imagined differently. It moves away from the mnemonic privilege accorded to artifact, monument, and text, instead focusing on "embodied memory: performances, gestures, orality, movement, dance, singing-in short, all those acts usually thought of as ephemeral, non-reproducible knowledge." ${ }^{16}$ At memorial sites, space and memory are therefore performed "live" by bodies saturated with social meaning.

Finally, traumatic memorial sites have increasingly been explained as dark tourism, in which death, disaster, and atrocity are offered as neoliberal tourist products. ${ }^{17}$ In Belfast, ex-paramilitaries now offer tours of murals, peace lines, and former bomb sites in the Post-Troubles city. ${ }^{18}$ Religious pilgrims in Bethlehem pay homage at the graffitiadorned Separation barrier and visit Banksy's Walled-off Hotel and Wall Museum. ${ }^{19}$ In postwar Lebanon, a recent survey suggests the untapped potential of dark tourism, particularly among a receptive youth who listed their interest in visiting cemeteries (Rafik Hariri; Wadih al-Safi and Martyrs' Cemetery Rawdat Al-Shaheedayn), former prisons (Khiam), and battle sites (Mleeta). ${ }^{20}$ Yet why should some sites be termed "dark" and morbidly voyeuristic while others are privileged as "cultural heritage" or "negative heritage" ? ${ }^{21}$ Does commodification and commercial exploitation lessen the authenticity or pedagogical impact of a former conflict site? While it is important to situate Lebanese war museums against a backdrop of communication and media technology, the Holocaust museum industry, ${ }^{22}$ and the marketization of memorial sites, it is essential to contextualize these sites more precisely to understand their purpose and appeal. Each of the following case studies will be understood within its own unique historical trajectory, examining its indexical nature, esthetic structure, and performative capacity. As Violi astutely observes, the "conservation, transformation and memorialization of places where slaughter, torture and horror have been carried out are key points for understanding better the relationship between memory and history in the case of each post-conflict society." 23

\section{Site and affect}

The three Lebanese memorial sites discussed in this article are located on symbolic borderlines and spatial rupture points: Mleeta is on the fringe of the former Israeli-occupied security zone in south Lebanon; Beit Beirut is on Beirut's Green Line wartime division, and Umam is in the Hezbollah-dominated Dahiyya suburbs of Beirut. These settings are not 
coincidental but are integral to each museum's mnemonic narrative, allowing events to be "inscribed with salience and meaning, and episodes and actions (and omissions) [to be] repositioned in relation to the present." ${ }^{24}$ Through this "spatial contiguity," each museum palimpsestuously layers the history of conflict with various regimes of memory and retrospective affective associations. As Laurie Beth Clark reminds us, the spatial remnants of conflict "do not do their work metonymically, that is, they do not stand in for the bodies of victims. Rather, they work affectively . . . deploying the visible residue of that trauma on the landscape." 25 This catalyzes some of the complexities of these museums, because it implies a particular claim to authenticity that non-site-specific monuments cannot access, yet more urgently poses the question of what an "authentic" narrative might tell us of the history of conflict by provoking a diverse and unpredictable affective response. In other words, through its spatial and affective work, the contiguity between content and context is likely to expand, rather than curb, the various reactions that each site might evoke in visitors.

\section{Mleeta, "where the land speaks to the heavens"}

Located on the decommissioned site of military clashes between Lebanese and Israeli fighters in the south of Lebanon, the Mleeta Resistance Tourist Landmark presents itself as a "natural museum." ${ }^{26}$ This evokes both its relationship to the mountainous landscape that surrounds it and the "naturalized" congruence between site and ideological message that the museum promotes. Inaugurated by the Lebanese political party and militia group Hezbollah in May 2010 (on the 10th anniversary of the south's liberation from Israeli occupation), the museum rehabilitates the pathways and tunnels used by Hezbollah fighters against Israeli forces. Indoor exhibition spaces and a cinema room showcase weaponry, artifacts, and photographs, while landscaped outdoor sections include viewing platforms giving onto the surrounding mountains, and a sculptural installation known as the Abyss. Argued by Mona Harb and Lara Deeb to play an important role in Hezbollah's creation of an "Islamic milieu" in Lebanon, Mleeta "brings history, memory and entertainment together and allows [visitors] to walk in the path of the fighters they admire and incorporate pride in the resistance into their senses of self." ${ }^{27}$ Mleeta memorializes conflict and occupation in the south primarily through the narrative of Hezbollah's success in liberating the region from Israeli occupation and its ongoing legitimacy as a protector of Lebanese territory. As elaborated in the introductory film, the museum narrates conflict at Mleeta within a continuous history of Israeli threat and Arab resistance dating back to 1948, incorporating the 1978 Israeli invasion of Lebanon and the 2006 conflict, when the enemy fell into a military and moral "abyss." The museum's architectural and curatorial design produces a site that can be "acted out"-or, more specifically in this case, reenacted-by visitors identifying with the resistance fighters who inhabited it, as well as a broader sentiment of Islamic resistance to Zionism.

Entering the site through an archway on which the museum's tagline "Where the Land Speaks to the Heavens" (hikayat al-'ard lil-sama) is emblazoned, visitors are first guided toward a group of low-rise buildings, housing an auditorium in the visitors' center where one can watch a film narrated by Hezbollah's secretary general Hassan Nasrallah, and an exhibition space. The architecture of these buildings, as well as the 
archway at the entrance, makes use of sharp diagonals and tilted, irregular shapes, of which the head architect Hajj 'Adil has stated: "We brought in the military by using diagonal walls, tilted ceilings, irregular openings, deep windows. We wanted to show how architecture can challenge straight lines, just like resistance challenged the enemy." ${ }^{28}$ While this seeks to symbolize and embody the spatial principles and expertise of the resistance, it also recalls the distinctive jagged architecture of other museums dealing with histories of conflict and genocide, notably including Daniel Libeskind's Jewish Museum, which opened in Berlin in 2001. 'Adil notes that the architectural team surveyed museums in the United States and Europe, including Holocaust museums, suggesting that Mleeta positions itself in relation to other war museums worldwide, and more pointedly through contesting or competing with the predominance of Holocaust memorials.

Following this section, visitors pass the Abyss, an installation comprising an Israeli Merkava-4 tank and multiple weapons; sculptures, such as a spider's web and destroyed Hebrew lettering (the acronym for the Israel Defense Forces); and scattered IDF boots and helmets. Given what Harb and Deeb describe as Mleeta's implication in a "transnational war of memory and history" as a "direct response to holocaust museums around the world," 29 these latter objects may or may not deliberately recall iconic images of piles of shoes and other items of clothing stacked by the Nazis in concentration camps. Activating the visitor's imagination through suggestion, their emptiness is more, not less, evocative of the bodies that would have worn them. Tour guides explain the symbolism of many of the objects: the spider's web, for example, represents the fragility of Israeli military force. The Abyss is said to be visible to Israeli satellites and planes, and presents a vivid depiction of resistance might and Israeli downfall. Visitors continue along a path through the trees, guided by panels in Arabic and English, and through tunnels dug by the resistance, passing bunkers, a kitchen, and a prayer room. The visit culminates at a large viewing platform at Mleeta's highest point before passing by the gift shop on the way out.

The land itself plays a key role in the ideological work of the museum; indeed, landscape may be a more suitable term for the natural environment experienced at Mleeta. This distinction suggests that "the 'nature' that is landscape's subject is never free from cultural coding" and that landscape is as much a discourse as an originary environment. ${ }^{30}$ Mleeta's personifying tagline, "Where the Land Speaks to the Heavens," scripts the land itself into the narrative presented. Visitors are prompted to view the mountains from locations affording splendid perspectives, such as the Lookout, an airy viewing platform giving onto villages that, the panel states, were liberated by the resistance from Israel in 1985. This is accompanied by the story of the martyr Sayyid Abbas al Moussawi's death in 1992, "preserving the Resistance." A long flight of steps to Martyr's Hill, a large viewing platform offering stunning 360-degree views of the mountains, concludes visitors' experience. In both cases, messages invoking sacrifice for the liberation and preservation of the Lebanese territory are underscored by idyllic perspectives over the hills and villages of the south and the journey visitors make from the dark spaces of the tunnels and pathways to the symbolic light and sense of futurity and hope lent by the striking views. Mleeta also functions, then, as a "supernatural" site-a space where sacrifice and martyrdom have sanctified and redeemed the land, creating a closer 
proximity to heaven. The inscription at the top of Martyr's Hill commemorates not only a national restoration of the homeland but also a spiritual liberation: "the blood on this field triumphs over the sword ... the blood shattered all the shackles." 31

The naturalness of this memorial site is also constructed through the relationship it presents between the location itself and the ideological message it conveys. In other words, the site-specificity of the museum works toward naturalizing (disguising) its ideological work. Stories suggesting that fighters were sheltered by the natural environment and their unique knowledge of the terrain contribute to a "discourse about the organic relationship of Resistance to land and nature." ${ }^{32}$ Visitors are repeatedly reminded that they are standing on the actual site of the resistance, not least by Nasrallah himself, who begins the introductory film's narration: "Here, on the very land that you stand on, the resistance fought and withstood." The museum presents spaces and artifacts as remnants of historical action: one guide pointed out an exploded cluster bomb, which he noted had been used by the Israelis, evidence of their violation of international human rights law. Walking "in the path of the fighters they admire," visitors situate themselves both spatially and ideologically within the legacy of the resistance. The visual strategies of the introductory film (e.g., filming through the weapon focalizers that are later physically re-encountered in the tunnels) immerse the viewer perspectivally, and by extension discursively, within the material and ideological history of the site. Both the evidence and affect of this history are immanent to the environment around us.

Mleeta balances care for the visitor (e.g., through direction from signs and tour guides, and through water fountains) with a level of physical hardship resulting from the heat and hilly terrain. This heightens the persuasiveness afforded by reenacting movement through the terrain and physically empathizing with the struggle of the resistance fighters. Along the paths and in the tunnels, lifelike mannequins of fighters occupy scenographies of flags, weaponry, and supplies. A newly opened Simulation Centre (summer 2018) further enables visitors to take up arms in a first-person shooter, multiscreen military simulation to defend Lebanon against an inevitable future Israeli invasion. Combining elements of reenactment, symbolism, and evidentiary material, then, Mleeta invites the visitor to participate in staging a richly personal relationship to the history of the site.

\section{Beit beirut: the urban fragments of war}

If the site-specificity of the Mleeta landmark functions to legitimize a dominant narrative of the past, that of Beit Beirut is far more ambiguous. Beit Beirut occupies a renovated villa dating from 1924, known as the Barakat Building (after the family who commissioned its design), situated on the northeast corner of the Sodeco crossroad on the Green Line of civil war demarcation. Offering a 270-degree perspective over the crossroad, the building was occupied by Lebanese Forces snipers during the war and suffered extensive material damage. In 2003, the Barakat building was expropriated on the grounds of public interest, and architect Youssef Haidar's renovation finally began in 2012, funded by Beirut's city council with guidance from the Mairie de Paris, the Institut Français, and a scientific committee made up of members from the cultural, 
academic, and civil society sectors. The restoration stabilized the structure and created high-specification facilities for exhibition and events inside the building, but much of the damage to the fabric has been kept visible.

Curators and artists working in the building have engaged in diverse ways with-and elicited varied responses to-its history. Scientific committee member Mona el Hallak, a high-profile campaigner for Beit Beirut, has given guided tours in the building alongside her exhibition of photographs, The Photo Mario Project. The first artistic exhibition to take place there, Sacred Catastrophe: Healing Lebanon by the visual and performance artist Zena el Khalil, addressed the building's associations with the civil war directly through a 40-day installation of artworks, performances, and workshops (18 September to 27 October 2017). Following this, the Arab Fund for Arts and Culture held a 10-year anniversary celebration at Beit Beirut in the form of a two-week exhibition curated by Rasha Salti (7-25 November 2017). Inviting more than 40 artists from 15 Arab countries, the exhibition leaned into its esthetic to gesture toward "the architectural incarnation of an allegory of Lebanon's Civil War, and perhaps the region's embattled contemporary reality." ${ }^{33}$ Both the interdisciplinary exhibition Shifting Lights (7 December 2017 to 2 January 2018) and the solo exhibition that followed it, Beirut: Echo of the Silence by Brahim Samaha (1-15 February 2018), used light as a metaphor for political instability, yet although Shifting Lights encouraged personal introspection stimulated by the "wounds" of the building, neither exhibition substantively foregrounded the building's particular history. ${ }^{34}$ Intercalated by an exhibition to celebrate the fashion designer Elie Saab's new dedicated postage stamp (31 March 2018), Haneen (21 February to 4 March 2018) and Nazra (from 15 May 2018) have both staged explorations of war memory in Lebanon, comprising exhibitions accompanied by events or discussions; the latter (with German funding) regrouped organizations, including the UNDP in Lebanon, the Lebanese Association for History, Committee of the Families of Kidnapped and the Disappeared in Lebanon, Fighters for Peace, and International Center for Transitional Justice. More recently, regular events, including book launches and sales for products from mosaics to designer scarves, would suggest that the space is used more for commercial hire than pedagogical curation.

For some of these interventions, the Barakat building provides an atmospheric backdrop that lends a certain political urgency to exhibitions with only tangential connections to the histories of the space and the city. Such examples may imbue them with a polyvalent association with the civil war that remains inclusive and open-ended, or draw on the building's history to make broader comments on political volatility in the region. However, they also risk divorcing the esthetics of the space from the circumstances of its dilapidation, inducting the building into the same economy of nostalgia that underlies much dark tourism in Lebanon.

The history of the space has been more directly confronted by interventions such as Nazra, The Photo Mario Project, and Sacred Catastrophe: Healing Lebanon. The Photo Mario Project displays a selection of some 10,000 negatives found in a photography studio that occupied one of the ground-floor shops in the building before the civil war. The exhibition has much in common with other works by Lebanese artists of the wartime generation that are based on found images-either real or imagined-and an interrogation of the historiographical concerns of the archive. ${ }^{35}$ Inviting visitors to "adopt" one of 
the portraits in search of the characters and stories it represents, el Hallak's exhibition asks: "How can we engage the public in researching this archive, and through their research connect them to the city and its memory?"36 Albeit within a framework of collective participation, the work thus invites a largely individualized, speculative engagement with prewar images. To an extent, this exhibition reclaims the building from its history of conflict into a celebration of the fashionable cosmopolitanism of mid-century Beirut, indexed by the stylized studio portraits: the civil war is mentioned only as a "time of resilience." ${ }^{37}$ While el Hallak's fervent protection of and research on the building would suggest a more directly activist project, such recourse to prewar narratives of the city has also been the focus of nostalgic imaginaries that elide the social inequalities present on the eve of the war, emphasizing a largely middle- and upper-class experience that draws attention away from the causes of the war.

Zena el Khalil's Sacred Catastrophe: Healing Lebanon was in turn more direct in addressing histories of violence. Alongside other works in el Khalil's exhibition, 17,000 $x$ Forgiveness, a large "forest" of green poles on the second and third floors, was installed in memory of the 17,000 people "disappeared" in the war, also evoking the foliage that gave the Green Line its name. The relative abstraction of such an installation, however, as well as el Khalil's chosen mantras of "love, compassion and forgiveness," position her work within a universal humanist paradigm that arguably makes an exhibition such as Sacred Catastrophe acceptable (if not uncontroversial) to the state administration. In her view, that the intervention took the form of an artwork also helped it to pass below the political radar:

It's a controversial topic, the disappeared. Because who made the people disappear? The people who are in public office today. ... [But] I wonder if, in general, people in Lebanon still think that art is not such a big deal. That they undermine it: it's just art. ${ }^{38}$

The views of those who have chosen to attend or avoid Beit Beirut have been varied. El Khalil describes young visitors born after the end of the war not recognizing the symbol of the Lebanese Forces on the walls and asking her the religion of the fighters: "And I'd always tell them, it doesn't matter, because this house is just like many other houses. So, we're not going to just identify one religion today. It doesn't matter if they were Christian or Muslim." 39 Visitors with first-hand or more partisan associations, however, brought their own stories to the space, such as a woman who remembered bringing food to the fighters in the building, or a former sniper who fought in the building as a teenager in the 1970s. According to the artist, the exhibition and workshops elicited suppressed discussions between friends who had no idea what the other had experienced during the war and repeated visits from neighboring residents.

Through the exhibition, el Khalil sought to offer healing through closure and to encourage visitors to share untold stories, both of violence and acts of kindness. "Everybody wants to talk about the war," she argues. "Everybody has something to talk about. But there is no space, there is no platform, there is no community center, there is no environment where real discussions can be had. But within this space, Beit Beirut, discussions were coming up, confessions were coming up, release was coming through." ${ }^{" 40}$ Despite any narrative that an exhibition or even permanent archival content in the museum might steer, however, the building has its own significations that are deeply personal. As one survey respondent confessed: "I couldn't care less about the 
exhibition to be honest. I was only interest[ed] in touring the building and I did" ${ }^{31}$; for another, the continuing presence of the ruins themselves is the most powerful and impactful reminder. While in el Khalil's account and in the ambitions of civil society players working in the space Beit Beirut offers opportunities for memory-sharing across sectarian divisions, the powerful affects of the space-its testimonies to extensive and largely unaccounted for acts of violence-could also have unpredictable and incendiary potential. As one respondent described: "The energy I felt inside the space was almost suffocating."

The disruptive power of the building's past is also matched by the socio-spatial significance and volatility of its location along Beirut's former Green Line. A political fallout in January 2018 between Amal (Nabih Berri) and FPM politicians (foreign minister Gebran Bassil) about leaked video insults resulted in Amal supporters engaging in street protests, road blockades, and tire burning in Mar Elias, Ras al-Nabaa, and Bechara alKhoury, which runs alongside Beit Beirut. ${ }^{42}$ As Lebanese politicians and the army scrambled to defuse urban tensions, it is evident that old fractures and rupture sites can be quickly imbued with fresh crises.

\section{Umam: archiving the civil war}

Unlike the other museums, Umam's memorial site is both physical and virtual. The organization's base and material archive is located within a traditional Lebanese villa compound in Haret Hreik, in Beirut's southern suburbs (Dahiyya). Established in 2004 by German filmmaker Monika Borgmann and Lebanese publisher and activist Lokman Slim, the emerging "citizen archive," a collation of newspapers, journals, and memoirs, has informed workshops, films, public discussions, and exhibitions held in an adjoining gallery space called The Hangar. The intended aim of Umam is the creation of a citizen resource center, which "helps boost collective reflection on the many different instances of conflict and violence that have plagued Lebanon's past, weigh heavily on its present and have the potential to influence its future." ${ }^{43}$

Alongside Umam's material archive is the more recent addition of a digital web-based portal titled "Memory at Work: A Guide for Lebanese on Peace and War." ${ }^{44}$ According to its website, this project (which is "under constant construction") aims to provide a dynamic "radical criticism" of the civil war through the creation of a repository of diverse voices and images. ${ }^{45}$ The bilingual database contains video clips of historic battles, interviews with combatants and civil society initiatives, alongside archival sections documenting Lebanese war memorials, political assassinations, the "disappeared," amnesty laws, war fronts, and maps of mass graves sites. ${ }^{46}$ For some of our Lebanese survey respondents, this project is long overdue and has the potential to create a collective, pluralistic database unhindered by local sensibilities or territorial divides. "I salute the initiative. It's a mammoth enterprise that needs to be undertaken, and the existing [website] is the tip of the iceberg . . . Memory at Work needs more exposure and deserves more attention from the public." Other respondents, however, raised concerns about the private nature of Umam D\&R and the potential agendas of its international sponsors (such as Heinrich Böll, EuropeAid, and Canada Fund), the tight control over who uploads material, and its apparent Western-leaning perspective: "it seems like it is 
designed by someone who doesn't live here." Such criticisms may reflect deeper concerns about foreign interference and political agendas; yet, a de-territorialized war memory archive does not alleviate questions about accessibility, control, and which war narratives are privileged.

If "Memory at Work" offers an online portal into Lebanon's contested past as "the first virtual museum of the Lebanese Civil War," ${ }^{\prime 47}$ Umam's organizational base in the predominantly Shia suburb and Hezbollah stronghold of Haret Hreik speaks of a very contemporary struggle over urban imaginaries and political control. Umam occupies the family villa of Lokman Slim, a gardened and walled property whose mandaloun-style Ottoman windows look out onto the densely populated high-rise neighborhood of Dahiyya. The villa is not a traumatic memorial site but, rather, a space that has withstood war, displacement, the transforming power of extensive Shi'i migration (Bekka and the south), and Hezbollah's political and administrative consolidation of the suburb. ${ }^{48}$ According to the Slims the building's historical longevity bears material witness to a bygone cosmopolitan Beiruti past where the Slim family (parliamentarian Mohsen Slim) would host parties for local and foreign dignitaries and the home would be an open space for communal discussion and debate. ${ }^{49}$ In this sense, the villa that houses the organization's physical war archives exemplifies Umam's memorial project of excavating a lost, neglected past and providing a space for critical historical narratives amid its increasingly sectarian environs. As Katherine Maddox notes: "The house embodies the future the organization wishes to project as well as a version of the past." ${ }^{n 0}$

For Lokman Slim, Umam's strategic location is not just about nostalgic longing but a recognition of Dahiyya's increasing importance within contemporary Beirut and wider Lebanon: "What is today central? Is Downtown [Beirut] central politically-wise, or Haret Hreik? I think we are much more central in all senses. Dahiyya is much more central because it has this value of at the same time fascination and fear." ${ }^{\text {51 }}$ Dahiyya's centrality for Slim is linked to Hezbollah's growing orbit of power within Lebanese politics-"we are a country which is itself under occupation." This is also felt through the Party's everyday inculcation of an Islamic urban milieu in the southern suburbs, embraced by their supporters as pious resistance and rejected by others as sectarian hegemony. Umam's secular and liberal credentials (serving alcohol, screening controversial films) challenge the religious conservatism of their neighborhood; more significantly, memorial projects such as "Collecting Dahiyya" provide alternative historical narratives that subvert Hezbollah's totalizing accounts. This exhibition, held in the aftermath of Israel's destructive 2006 war, included posters, photos, interviews, Dahiyehscope (a series of short films shot during the war), and an interactive whiteboard map that encouraged guests to contribute to the dynamic recreation of the southern neighborhood. The testimonies and stories of Christian inhabitants before the civil war emphasized the homogenizing logic of displacement and sectarian ghettoization. As Slim explained to a local newspaper reporter at the opening of the exhibition: "I don't want to live in a country that is a collection of Dahiyehs, yet I see that's what's happening. Without making an effort Dahiyeh has become the mirror of what ... Tariq al-Jadideh, Chouf and others are becoming." 52

Umam's interventions provide a dynamic and shifting memorial landscape, one that seeks to entwine historic material archives (Villa Slim) and artistic engagement through 
exhibitions, installations, and cultural events in The Hangar. The Hangar, as Maddox explains, is a "space where 'fictional potentialities' and 'interpretations of fact' that arise from the contestation of the nation are addressed through artistic and cultural interventions with the hope of arriving at some definite answer. ${ }^{n 3}$ The fusion of material sources and imaginative interpretation represent the challenge of reconstructing the Lebanese past within a very precarious present. Monika Borgmann's story of Umam's encounter with the Ain el-Remmaneh bus is indicative of this struggle:

For three years between 2011 and 2013, the famous bus of Ain el-Remmaneh was in UMAM. The civil war started with an accident with a bus. So, this bus was here. It was first part of an exhibition we organized, then the exhibition after two months ended the real bus stayed here in our place . . . We found the bus ourselves, the bus was in the South. We brought it here, and then it stayed. And as it was attracting huge amount of people, a lot of press and so on, today's owner thought he could make a lot of money with it. So, he asked us to buy the bus for US $\$ 200,000$. Which we didn't have, of course. So, he took his bus back. Now it's somewhere in the South. ${ }^{54}$

Umam's recovery and display of the bullet-ridden bus was inspired and accompanied by Houssam Boukeili's artistic exhibition of silkscreen prints of Lebanese buses, $A$ Bus and its Replicas (2011). Viewers were invited to make "critical leaps between memory repositories and artifacts assembled," 55 yet the activist-artist collaboration also raised questions of appropriation. As Borgmann recounts, the discovery of this infamous war relic did not lead to official preservation but, rather, resulted in a private dispute over its financial value and ownership. Boukeili recalls a heated argument between the current bus owner and the son of the former bus driver, upset that the bus had not been passed on to him: "But why are you talking about my father? You do not know my father, it is our history." 56 Such memorial exhibitions not only provoke debates about who has the right to tell Lebanon's violent histories but also reveal the emotive power of war artifacts to disturb and challenge present realities.

\section{Narratives and nation}

With the exception of the city council's somewhat inconsistent guardianship of Beit Beirut, none of the memorial museums under review are officially state sponsored or administrated sites, yet they cannot be disentangled from nationalist claims. The absence of the Lebanese state is a common postwar lament, but in the case of each museum there is a negotiation of the state's (failed) role retold through memorial practice. $^{57}$ At Mleeta, Hezbollah assumes the role of Lebanon's national defender against Israeli aggression, a consequence of the military failings of the state apparatus. Umam takes up the mantle of archivists responding to the state's deliberate obfuscation of national war memory. Beit Beirut, in its incomplete status, indicates a Lebanese state willing to acknowledge the urban legacy of violence but reluctant to take responsibility for a critical historical examination of the past. Each memorial museum thus provides a complex snapshot of the ongoing debates surrounding Lebanon's postwar politics. 


\section{Wayn al-Dawala? Where is the state?}

During Mleeta's inaugural year (2010-2011), the site was visited by former Lebanese president Emile Lahoud and tourism minister Fadi Abboud, and was embraced as part of the national tourist development plan for south Lebanon. Alternating Lebanese and Hezbollah flags flanked the entrance and stood side by side on the hilltop lookout, symbolizing the complementarity of both the Lebanese state and the Islamic resistance. Eight years later, only Hezbollah flags adorn Mleeta's entrance and the hilltop. ${ }^{58}$ Memorabilia intermingling Lebanese and Hezbollah colors can still be purchased in the gift shop, but the nation state is less visible in the esthetic contours of this memorial site. This symbolic decision undoubtedly reflects the complexity of Hezbollah's relationship with the state since their unsanctioned military involvement in the Syrian civil war in early 2013. It may be interpreted as an attempt to uncouple Hezbollah's resistance operations from the Lebanese government's "disassociation" policy in Syria. Alternatively, it may simply reflect the Party's growing self-confidence that it does not need to prove its Lebanese credentials or indeed share its military victories with the Lebanese state. The latter reading supports Mleeta's overall resistance narrative, which exclusively privileges Hezbollah and erases all other Lebanese resistance histories (such as those of Amal, SSNP, and the Communist Party). Mleeta's curation and introductory film eschews Hezbollah's emergence and involvement in the Lebanese civil war, but rather imagines it solely as a liberatory people's movement engaged in an existential battle with an Israeli Zionist enemy that goes beyond national borders and state sovereignties. As Hatim el-Hibri explains: "The museum's task is twofold-to give institutional form to the party's (and therefore the people's) history of guerilla resistance to Israeli occupation, while at the same time making the claim that this specific history is one of national or even universal significance. ${ }^{n 9}$ Hezbollah's current military engagement in Syria, absent from the discourse at Mleeta, is similarly framed as a fight to protect the Lebanese State (and all of its people) through an existential battle against another exclusionary ideology threatening the Middle East: "Salafi takfiri terrorism."

The Mleeta museum has a claim on Lebanon's future as well as its past. Its key ideological imperative is to promote Hezbollah's ongoing necessity in continued resistance to Israel. As much as the spaces, artifacts, and audiovisual material make use of evidentiary and symbolic tropes to persuade visitors of a certain narrative of the past, so they must also tell a particular story about the future. In the words of our survey respondents, Mleeta "helps to keep the creation of an enemy happening"; "You come out [from the museum] ready to fight for your rights"; "It not only recounts past history but the present and all the propaganda that goes with it."

\section{Truth telling from below}

Umam presents itself as cultural custodian of Lebanese war archives, independent from the state and antithetical to the ongoing policy of public censure and denial: "the collection being built by UMAM D\&R is destined for Lebanon's public, and . . is open to everyone without the restrictions imposed by State or academic entities." ${ }^{\prime 61}$ In this, civil society is seen as autonomous and separate to the state. Umam is certainly a challenger of the Lebanese political establishment, yet its commitment to promote debate and 
public discussion of the civil war (and its legacy) through "multiple narratives" of the past is not without agency or political intent. In the organization's own words, it seeks to challenge "the country's faulty national memory" and provide a platform "upon which to assess and help deal with Lebanon's current problems and challenges." A number of Umam's projects shift between past and present temporal frames, moving from "truth seeking" to "truth telling," addressing the Lebanese disappeared (Missing, 2008), war crimes and amnesties (What Is to Be Done? Lebanon's War-Loaded Memory, 2008-2009), military (in)justice (Martial Justice for All? Lebanon's Military Court: A "State of Martial Law" within a "State of Law," 2014-2015), and peace initiatives (Peace upon You: Revisiting Past Attempts to End Lebanon's Conflicts, 2015-2016). ${ }^{62}$ Two more recent projects directly confront the most pressing and sensitive of national topics: Syrian refugees and the nature of the Lebanese state. Most Welcomed? Lebanon through its Refugees, a series of papers and public workshops held in 2017-2018, offered a critical examination of Lebanon's historic positions on asylum and refugees, seeking to move the debate beyond security concerns and economic cost and instead suggesting that the polarizing and partisan disputes about refugees represents "an integral component of the enduring debate over Lebanese national identity." ${ }^{13}$

Umam projects are not explicitly policy orientated, yet the cannot be dissociated from secular liberal politics seeking to challenge Lebanon's postwar sectarian status quo. Equally, while representing local voices and interests, Umam remains dependent on international funding and is therefore responsive to donor research agendas and global trends. The neoliberal influx of foreign capital into Lebanon following the end of the civil war (1990) and the Syrian withdrawal (2005) created new dependencies, audiences, and discourses for civil society and artistic initiatives. As Hanan Toukan persuasively argues, a 1990s and early 2000s cohort of Lebanese artists and cultural organizations "tied itself to international funding for cultural production and embedded itself within a process of producing and international exhibiting that valorizes culture ... a professionalized form of art where, some have argued, politics becomes the art of display." ${ }^{164}$ This trend is perhaps evidenced by Umam's privileging of the English language in publications, public events, and on their website (although Arabic translations are available for some of the work), or, indeed, reflected in recent internationally funded projects on Syrian prisons and prisoners (Shared Suffering: Exploring the Abyss of Syrian Prisons, 2012-2013) and the construction of a new online database Memory at Work Syria: A Toolbox for Rethinking Syria (2014- ) sponsored by IFA and the German Federal Foreign Office. The professionalization, or "NGO-ization," of civil society initiatives, as Hammami warns from the Palestinian context, can both de-politicize and distance organizations from their social bases, who become "social groups in need of instruction" rather than "constituencies from which they take their direction and legitimacy." 65 Umam D\&R's truth telling from below is certainly complicated by its funding from barra (outside), while its commitment to instruct and "guide" Lebanese into new narratives of the past seeks to affect real change in the present. This is not to critique Umam's postwar contribution, but rather to identify that its memorial work is invested in reaffirming a cosmopolitan and pluralistic form of Lebanese nationalism. Among many of our Lebanese respondents, Umam still offers the greatest potential as a war memorial initiative, but it also requires an "expanded database," which is fully 
"open-sourced," providing more space for the uploading of everyday "stories, pictures, diary records, newspaper articles that would give even more details about what happened."

\section{Political stickiness}

While Beit Beirut advertises itself as a museum and urban cultural center, it is not currently operating as such, a conundrum indicative of what el Khalil euphemistically terms the "political stickiness" of state involvement in the project. ${ }^{66}$ A competitive bid was held for curatorship of the space, and although a winner was selected a contract was never signed. The space is therefore ready, but lacking a permanent curator, and administrative and logistical delays are suspected by some to belie political unwillingness. As described earlier, a number of artistic and archival exhibitions have since taken place with varied relationships to the space, the history of Beirut, and the civil war (or none at all), but at the time of writing there is no permanent museum content and much of the building lies empty.

The reemergence of war actors as part of the contemporary government makes the histories of violence told by the museum potentially irreconcilable with state narratives of willful forgetting. To install a permanent exhibition in Beit Beirut-that is, to turn the building from a memorial site into a museum-would be a radical step toward an official history of the civil war. In el Khalil's words, through the involvement of the city council, "the government's face is on this building." ${ }^{67}$ Not only would it be near impossible to agree on what this narrative should recount (given ongoing political-sectarian division concerning war history at both party-political and popular levels), it would also implicate the state in acknowledging the violent past of the present political elite. As Umam's director Lokman Slim regretfully stated of Beit Beirut: "We don't have any policy to deal with the legacy of violence in this country. How can we imagine that such a project will find its way? The whole system finally is based on amnesia, just turning the page, non-accountability. It doesn't work, it's just delusional." ${ }^{38}$ While individual players, such as the exhibiting artists, sympathetic civil society organizations, campaigners, and others, might express a certain position or narrative vis-à-vis the war through personal projects and temporary interventions in the space, it is yet to be seen whether the museum can or will accommodate any permanent historical content under its official pedagogical remit, and thus whether the narrative(s) it presents will stake any claim to national representation.

While the building is officially (and financially) in the care of the city council, the effort of el Hallak and the scientific committee was most visibly behind the expropriation and restoration, and Beit Beirut remains widely understood as a civil society project rather than a state one. As one survey respondent expressed, the restoration of Beit Beirut "is in contrast with the erasure of the war from the Beirut city center. So also political in many ways, maybe catering more towards the bourgeoisie left-with its arts exhibitions and programing." In this case, and similarly to Umam, Beit Beirut is seen as diverging from the state's approach to war memory, not least as a building that has been restored with the signs of violence left intact, rather than reconstructed in the 
Solidere fashion. Yet for this respondent, its programing remains political in leaning toward the ("bourgeoisie left") agenda of a middle-class civil society constituency.

However, universal, humanistic rhetorics can help to disguise politics. El Khalil's thinking on this issue is revealing: "Whoever becomes the curator is in a position of great responsibility. Because they're telling the story of the city. You see I just assumed that it would be, like, one of us, you know? One of the good guys! But what if it wasn't?" "The apparently unificatory narrative of Beirut's history (the "good" and "right" narrative: "peace and love") seems to achieve transparency as the appropriate history of the city thanks to its apparently inclusive and conciliatory stance. Yet while a number of the survey respondents suggested that a national museum of the civil war should be managed by institutions such as the Ministry of Education or the nonprofit and civil society sectors, none of these can be realistically considered apolitical nor disinterested in the implications of war memory in Lebanon today. The impasse at which Beit Beirut finds itself is indicative of the contemporary politics of war memory in Lebanon in which neither party, nor state, nor civil society is neutral, and in which neither reconstructed downtown Beirut nor the Green Line are universally experienced as accessible sites of encounter.

Whether the historiographical ambivalence of many of the exhibitions at Beit Beirut is employed strategically to induct political statements into the space "under the radar," the arts have been invoked as inclusive terrains on which remembering can take place without directly undermining the current regime. However, artworks and events curated in Beit Beirut hold messages and invitations to their viewers that are socially situated, selective, and ultimately cannot avoid being political in nature. Despite the ambiguous metaphors of light and sound in Echo of the Silence; the attention to personal, subjective narratives invited by The Photo Mario Project; or the focus on universalist themes of love, compassion, and forgiveness espoused by Sacred Catastrophe, such interventions may well activate an array of unforeseeable responses from visitors inspired toward accountability, reconciliation, or political action in Lebanon, particularly for those with first-hand memories of the civil war. El Khalil's account of a former sniper's experience of her exhibition in Beit Beirut attests to this:

Everybody who came, came because they needed to vent about the war, they needed to share, they needed to communicate, to connect, they needed to release. There was a sniper who used to fight there in the late '70s, and he hadn't come back since then. During the exhibition it was the first time he came through since he was 18 years old, 16 I think, fighting there. He came in with his daughter, and it was a very big deal for him. And he took her around and he showed her everything, and at the end he came and introduced himself to me. And I was very surprised that he would openly say, I used to fight here. No remorse in his voice. I told him why, you know, what made you carry a gun? And he said, for love. Love of my people and our way of life. Against the other. And for him at that time the other were the Palestinians. ... And he thanked me, because when you first walk in on the first floor there was a huge sculpture on the floor that said "Forgiveness". There were tiles with the word "Forgiveness" printed 108 times. So that's the first thing you see when you walk into the big space. And he said, I walked in and you forgave me. ${ }^{70}$

Such an encounter of forgiveness and closure allows for a discussion about the war to take place without concrete demands for social justice or change in Lebanon. The approach does not insist on the link between the wartime history of Beirut and the 
aftermaths experienced by Lebanese youth: the injustices permitted by the Amnesty, political corruption and deadlock, breakdowns in public services, and widespread social inequality. Narratives of universal forgiveness-reconciliation without accountabilitytherefore risk failing to place young people in Lebanon in a position of informed agency with regard to the current political regime and the future of the nation.

\section{Conclusion}

To take these three case studies together evidences the still-contested nature of war memory in Lebanon. As members of the first generation to be born after the civil war now come of age as key stakeholders in the future of the nation, no clear way of moving forward with shared narratives of the past is evident. As has been widely agreed since the early 1990s, the absence of coherent memory at a national level has led to the proliferation of narratives at the level of the family, neighborhood, and party as well as among a largely middle-class civil society struggling to represent national interests. As Hermez provocatively suggests, "civil society ensured the continual recollection of Lebanon's war into the present, but unable to deal with the war's causes, facilitated war's anticipation into the future." ${ }^{71}$ These war museums attest to diverging accounts and strategies. Mleeta attempts to displace the legacy of a destructive and fractured civil war with a triumphant liberatory struggle against Israel-the failure of the Lebanese state replaced with the victory of the Islamic resistance. Umam seeks to uncover a suppressed past that will both challenge the basis of Lebanon's sectarian politics and offer new ways forward. Beit Beirut, product of a decades-long struggle to preserve one of the city's most evocative monuments, must now find ways to make good on its pedagogical mission, even while negotiating the reluctance of the state to associate itself with histories of civil violence.

As Bharucha has argued, "the prefix of 'post-' . . . is deceptive in so far as it implies a clean break with the past, which, in actuality, continues to haunt the present through lingering legacies of violence, humiliation, and injustice."72 In Lebanon's "post-"civil war moment, the country is clearly haunted by the fragments, architectures, and stories of past conflict, but it is also experiencing a present in which the political regimes that fostered war are have been retained or recast. For Lebanese youth, this has produced catastrophic levels of inequality, environmental damage, and political disenfranchisement, all of which stand to be renegotiated by this generation through effective engagement with the histories of the present. Interest in the three museums discussed here points toward desire among Lebanese youth for national war museums that could "bring together composite materials and multiple testimonies" from fighters, martyrs, victims, and citizens. While most agree on the pedagogical purpose- "to educate about the mistakes of the past," "repentance and learning"-few, however, are ready to believe in its political feasibility or public acceptance.

\section{Notes on contributor}

Craig Larkin is senior lecturer in comparative politics of the Middle East, Department of War Studies, King's College London. His research interests include memory and transitional justice, urban geopolitics, and Islamist movements, religion, and identity politics. 
Ella Parry-Davies is a British Academy postdoctoral fellow at the Royal Central School of Speech and Drama, University of London, where her research focusses on relationships among performance, urban space, and memory making in contexts of migration.

\section{Notes}

1. Claire Launchbury, Nayla Tamraz, Roger Célestin, and Eliane DalMolin, "War, Memory, Amnesia: Postwar Lebanon," Contemporary French and Francophone Studies 18, no. 5 (2014): 457-61; John Nagle, "Ghosts, Memory, and the Right to the Divided City: Resisting Amnesia in Beirut City Centre," Antipode 49, no.1 (2017): 149-68.

2. Sune Haugbolle, War and Memory in Lebanon (Cambridge: Cambridge University Press, 2010), 8-9.

3. Katharine Hodgkin and Susannah Radstone, eds., Regimes of Memory (London: Routledge, 2003).

4. See http://www.beitbeirut.org; https://mleeta.com/mleeta/eng/; https://umam-dr.org/en/ home; and http://www.memoryatwork.org/.

5. Craig Larkin, Memory and Conflict in Lebanon: Remembering and Forgetting the Past (London: Routledge, 2012); Ella Parry-Davies, "Ecologies of Remembrance: Performance, Place and the Past in Singapore and Beirut" (PhD dissertation, King's College London and National University of Singapore, 2017).

6. See Peter Vergo, ed., The New Museology (London: Reaktion Books, 1989); Paul Williams, Memorial Museums: The Global Rush to Commemorate Atrocities (Oxford: Berg, 2007); Eilean Hooper-Greenhill, Museums and the Interpretation of Visual Culture (London: Routledge, 2000).

7. Williams, Memorial Museums, 8.

8. Silke Arnold-de Simine, "Memory Museum and Museum Text: Intermediality in Daniel Libeskind's Jewish Museum and WG Sebald's Austerlitz," Theory, Culture and Society 29, no. 1 (2012): 18.

9. Dora Apel, Memory Effects: The Holocaust and the Art of Secondary Witnessing (New Brunswick, NJ: Rutgers University Press, 2002).

10. Jens Andermann and Silke Arnold-de Simine, "Introduction: Memory, Community and the New Museum," Theory, Culture and Society 29, no. 1 (2012): 9.

11. Susan Sontag, Regarding the Pain of Others (London: Penguin, 2004), 103.

12. Leo Benedictus, "Are the $9 / 11$ Museum's Commemorative Toys and Hoodies a Step Too Far?” https://www.theguardian.com/culture/shortcuts/2014/may/19/911-museum-gift-shopbad-taste-new-york (accessed 22 Aug. 2018).

13. Alys Cundy and Yvonne Pörzgen, "Emotional Strategies in Museum Exhibitions," Museum and Society 14, no. 3 (2016): 359-62.

14. Patrizia Violi, "Trauma Site Museums and Politics of Memory: Tuol Sleng, Villa Grimaldi and the Bologna Ustica Museum," Theory, Culture and Society 29, no. 1 (2012): 39.

15. Barbara Kirshenblatt-Gimblett, Destination Culture: Tourism, Museums, and Heritage (Berkeley: University of California Press, 1998); Diana Taylor, The Archive and the Repertoire: Performing Cultural Memory in the Americas (Durham, NC: Duke University Press, 2003).

16. Taylor, The Archive and the Repertoire, 20.

17. J. John Lennon and Malcolm Foley, Dark Tourism: The Attraction of Death and Disaster (London: Continuum, 2000).

18. Madeleine Leonard, "A Tale of Two Cities: 'Authentic' Tourism in Belfast," Irish Journal of Sociology 19, no. 2 (2011): 111-26.

19. Craig Larkin, "Jerusalem's Separation Wall and Global Message Board: Graffiti, Murals, and the Art of Sumud," The Arab Studies Journal 22, no. 1 (2014): 134-69.

20. Socrat Ghadban and Manar Abou Zaki, "Dark Tourism in Lebanon: A Bright Opportunity to be Pursued," International Journal of Tourism and Hospitality Reviews 2, no. 1 (2015): 53-60. 
21. Michael S. Bowman and Phaedra C. Pezzullo, "What's So 'Dark' about 'Dark Tourism'? Death, Tours, and Performance," Tourist Studies 9, no. 3 (2009): 187-202; Lynn Meskell, "Negative Heritage and Past Mastering in Archaeology," Anthropological Quarterly 75, no. 3 (2002): 557-74.

22. Andreas Huyssen, Present Pasts: Urban Palimpsests and the Politics of Memory (Stanford, CA: Stanford University Press, 2003).

23. Violi, "Trauma Site Museums and Politics of Memory," 37.

24. Cillian McGrattan, "Policing Politics: Framing the Past in Post-conflict Divided Societies," Democratization 21, no. 3 (2014): 391.

25. Laurie Beth Clark, "Ruined Landscapes and Residual Architecture," Performance Research 20, no. 3 (2015): 84.

26. Mleeta Resistance Tourist Landmark, https://mleeta.com/mleeta/eng/ (accessed 22 Aug. 2018).

27. Mona Harb and Lara Deeb, "Culture as History and Landscape: Hezbollah's Efforts to Shape an Islamic Milieu in Lebanon," Arab Studies Journal 19, no. 1 (2011): 26.

28. Ibid., 25.

29. Ibid., 27.

30. Elinor Fuchs and Una Chaudhuri, eds., Land/Scape/Theater (Ann Arbor: University of Michigan Press, 2002), 12.

31. This inscription is part of Nasrallah's "Day of Victory and Liberation" speech, 25 May 2000.

32. Harb and Deeb, "Culture as History and Landscape," 27.

33. "Ten Years Later: AFAC Celebrates its 10th Anniversary with more than 40 Artists from 15 Arab Countries," https://arabculturefund.org/bulletin/article.php?genre=2\&id=917 (accessed 22 Aug. 2018).

34. "Shifting Lights Exhibition," http://twigcollaborative.com/article/66 (accessed 22 Aug. 2018).

35. See Sarah Rogers, "Out of History: Postwar Art in Beirut," Art Journal 66, no. 2 (2007): 8-20.

36. The Photo Mario Project, Beit Beirut, wall panel.

37. Ibid.

38. Zena el Khalil, interview with the author, 11 Feb. 2018.

39. Ibid.

40. Ibid.

41. Online survey conducted among 40 Lebanese youth through snowballing contacts, during Jan. 2018.

42. Hussein Dakroub, "Bassil Video Puts Lebanon on Edge," Daily Star (Lebanon), 30 Jan. 2018.

43. "About Us: Mission Statement," https://www.umam-dr.org/en/home/about-umam/1/ advance-contents/3/mission-statement (accessed 22 Aug. 2018).

44. The Digital archive was funded after the 2006 war as part of the restoration of The Hangar and digitization program by the Dutch Ministry of Foreign Affairs through the Prince Claus Fund for Culture and Development.

45. "Memory at Work," http://www.memoryatwork.org/index.php/2 (accessed 22 Aug. 2018).

46. The English translation and archive materials are not as extensively developed as the initial Arabic component of the website.

47. Monika Borgmann, quoted in Isabelle Mayault, "Looking for the Lost Bus," Mashallah News, https://www.mashallahnews.com/looking-for-the-lost-bus/ (accessed 22 Aug. 2018).

48. Lara Deeb, An Enchanted Modern: Gender and Public Piety in Shi'i Lebanon (Princeton, NJ: Princeton University Press, 2006).

49. See memoir and interview material from Umam D\&R "Collecting Dahiyeh" exhibition, 2007.

50. Katherine Maddox, "Archiving the Present in Beirut's Southern Suburb: Memory, History, and Power at Umam Documentation and Research" (PhD dissertation, University of Texas, 2016): 23.

51. Lokman Slim, interview with the author, 14 Feb. 2018. 
52. Jim Quilty, "Putting Flesh and Bones on the Specter of Dahiyeh," The Daily Star, 8 June 2007.

53. Maddox, "Archiving the Present in Beirut's Southern Suburb," 68.

54. Monika Borgmann, interview with the author, 14 Feb. 2018.

55. "A Bus and Its Replicas," https://www.umam-dr.org/en/home/projects/14/advance-contents/ 115/a-bus-and-its-replicas (accessed 22 Aug. 2018).

56. Houssam Boukeili, quoted in Isabelle Mayault, "Looking for the Lost Bus," Mashallah News, https://www.mashallahnews.com/looking-for-the-lost-bus/ (accessed 22 Aug. 2018).

57. Jamil Mouawad and Hannes Baumann, "Wayn al-Dawla? Locating the Lebanese State in Social Theory," Arab Studies Journal 25, no. 1 (2017): 66-91.

58. During separate visits to Mleeta in 2018 the Hezbollah flag and the Lebanese flag were flown alternately from the hilltop. As a Mleeta guide commented: "At times we swap them round. This month it is the Lebanese flag as we recognize the Army's support for Hezbollah's victories in Arsal." Interview with the author, 8 Sept. 2018.

59. Hatim el-Hibri, "Disagreement without Dissensus: The Contradictions of Hezbollah's Mediatized Populism," International Journal of Communication 11 (2017): 42-45.

60. See Hassan Nasrallah, "Why Hezbollah Is Fighting in Syria," speech on 16 Feb. 2014, https://www.dailymotion.com/video/x6fud9x (accessed 22 Aug. 2018).

61. "The Collection," http://www.umam-dr.org/en/home/categories/13/our-collection (accessed 22 Aug. 2018).

62. "Projects and Events," https://www.umam-dr.org/en/home/categories/2/our-work (accessed 22 Aug. 2018).

63. "Fewer Refugees-More Refugeeism," https:/www.umam-dr.org/en/home/projects/14/ advance-contents/188/fewer-refugees-more-refugeeism (accessed 22 Aug. 2018).

64. Hanan Toukan, "On Being the Other in Post-Civil War Lebanon: Aid and the Politics of Art in Processes of Contemporary Cultural Production," The Arab Studies Journal 18, no. 1 (2010): 144 .

65. Rema Hammami, "Palestinian NGOs since Oslo: From NGO Politics to Social Movements?" Middle East Report 214 (2000): 19.

66. Zena el Khalil, interview with the author, 11 Feb. 2018.

67. Ibid.

68. Slim, interview, 2018.

69. el Khalil, interview, 2018.

70. Ibid.

71. Sami Hermez, War Is Coming: Between Past and Future Violence in Lebanon (Philadelphia: University of Pennsylvania Press, 2017), 192.

72. Rustom Bharucha, Terror and Performance (London: Routledge, 2014), 104. 